\title{
BUtTERfLIES OF the Rice ReSEARCH StATION AND ADJOINING LOCALITY IN CHINSURAH, WEST BENGAL, INDIA
}

Abstract: Chinsurah is a small town on the western bank of the Hugl River, a distributary of the river Ganges. A survey from November 2006 to June 2014 with photographic documentation on the butterfly community in Chinsurah revealed the presence of a total of 70 species representing 53 genera in five families; most dominant family was the Nymphalidae having $34.3 \%$ of the total species. Six species are legally protected; one species under Schedule I; three species under Schedule II; and two species under Schedule IV of the Indian Wildlife (Protection) Act, 1972. Rare species like Pareronia avator (Moore), Mahathala ameria (Hewitson) and Melanitis zitenius (Herbst) were recorded in this rapidly degrading habitat. This study may help in planning conservation strategies in urban areas and sustainable development as well.

Keywords: Butterfly diversity, Hooghly River, insect diversity, Lepidoptera, Lycaenidae, lower Gangetic plain, Nymphalidae, urban conservation.

The Rice Research Station (RRS), Chinsurah was established in 1932. Previously it was known as 'Chinsurah Farm'. It is the main RRS in West Bengal and the campus area is approximately one square $\mathrm{km}$. This walled area is situated between the urban and rural habitations of Chinsurah, which lies about $40 \mathrm{~km}$ north of Kolkata on the bank of Hugli River. The area between the river and the RRS is densely populated. The western side of the RRS is surrounded by mango orchards and cultivated fields. There is no trace of forest in the entire area and the vegetation is composed of local weeds, shrubs and planted trees. According to agro-climatic zonation Chinsurah is part of the Gangetic alluvial zone with clay loam type of soil and is very fertile (Adhikari et al. 2011; Bhowmik et al. 2014). The entire habitat in this area is rapidly degrading due to extensive urbanization.

The butterflies are our most fascinating arthropod neighbors that act as an important indicator of climate change and environmental degradation. The biology of this group of insects is being studied since time immemorial (Kehimkar 2008). A part from their ecological importance butterflies and large moths are considered flagship species to promote insect conservation and resource protection (New 2011). Therefore, natural history studies on butterflies are still essential for the maintenance of biological diversity and conservation purposes. The butterfly fauna of India consists of about 1,504 different species. Diversity of butterflies in West Bengal seems to be very high especially in the northern region as, 161 species have been recorded from the Neora Valley National Park (Sengupta et al.

DOI: http://dx.doi.org/10.11609/jott.2815.8.5.8804-8813 | ZooBank: urn:Isid:zoobank.org:pub:76973ADA-FBAB-44D2-BD98-E0C71BE818B1

Editor: George Mathew, Kerala Forest Research Institute, Peechi, India.

Date of publication: 26 May 2016 (online \& print)

Manuscript details: Ms \# 04089 | Received 03 July 2015 | Final received 04 May 2016 | Finally accepted 07 May 2016

Citation: Mandal, S. (2016). Butterflies of the Rice Research Station and adjoining locality in Chinsurah, West Bengal, India. Journal of Threatened Taxa 8(5): 8804-8813; http://dx.doi.org/10.11609/jott.2815.8.5.8804-8813

Copyright: () Mandal 2016. Creative Commons Attribution 4.0 International License. JoTT allows unrestricted use of this article in any medium, reproduction and distribution by providing adequate credit to the authors and the source of publication.

Funding: Self funded.

Conflict of Interest: The author declares no competing interests.

Acknowledgement: I would like to extend my sincere gratitude to Mr. Achintya Kumar Paul, Officer-In-Charge, Durgapur Government College, Durgapur, West Bengal, India and Dr. Subhra Kumar Mukhopadhyay, Principal, Hooghly Mohsin College, Chinsurah, West Bengal, India for their constant encouragement to carry out the work. I would like to thank Dr. Tapas Kumar Misra, Head of the Department of Zoology, Jhargram Raj College, Jhargram, West Bengal, Dr. Pradip Kumar Kar and Dr. Susanta Roy Karmakar Assistant Professors of the same department for their generous help in different aspects of the work. I am also thankful to Dr. Samir Kumar Saha, Assistant Professor, Department of Zoology, West Bengal State University, Barasat, West Bengal and Dr. Suprotim Mukherjee, Assistant Professor, Dept. of Zoology, Raja Ram Mohan Mahavidyalaya, Khanakul, West Bengal for allowing me to use their compact digital cameras. 
2014). On the other hand, only 76 butterfly species were recorded from the globally famous deltaic ecoregion, the Indian Sundarbans, with poor abundance (Chowdhury 2014). Study areas in both the reports were away from urban areas. The recent worldwide trend of urbanization is causing habitat degradation, destruction and fragmentation (Bates et al. 2014). In another case, severe anthropogenic stress has been assumed to be the cause of lower butterfly species diversity in Oussudu lake area in southern India (Murugesan et al. 2013). Therefore to propagate the conservation in urban areas further studies are necessary. An attempt was made to study and document the butterfly species diversity in Chinurah, West Bengal, having both urban and rural habitation. The present study was centered on the Rice Research Station, Chinsurah and adjoining areas extending up to the western bank of the Hugli River.

\section{MATERIALS AND MethodS}

\section{Study area}

The RRS, Chinsurah is located $22^{\circ} 52^{\prime} \mathrm{N} \& 88^{\circ} 24^{\prime} \mathrm{E}$ at an altitude of $8.62 \mathrm{~m}$ (Bhowmick et al. 2014). The area marked with red lines on the map indicates the boundary of RRS, Chinsurah (Fig. 1). The entire eastern and the southern sides of the RRS are densely populated by human habitation. The other two sides are rural areas with mango orchards and cultivated lands. The roadsides in RRS or in the rural areas contain bushes of Lantana sp. and other weeds. Additional to that, there are some ponds and ditches of various sizes of which, the sides are covered with bushes of weeds. On the other hand, the roadsides of urban areas are almost clean or scantily covered with weeds. There are some vacant lands in the urban area that are densely covered with weeds. These weeds and some garden plants attract the butterflies in the urban area. The western bank of the Hugli River is the easternmost boundary of the study area and it supports a large array of weeds and plants that attract butterflies. The climate of the study area is tropical and humid. The temperature normally varies from $24-40{ }^{\circ} \mathrm{C}$ during summer and from $7-26{ }^{\circ} \mathrm{C}$ during winter. According to Bhowmick et al. (2014), the average normal annual rainfall measured in RRS is $1453.7 \mathrm{~mm}$ of which, the maximum occurs during May-October.

\section{Sampling and other methods}

This study was carried out during November 2006 to May 2014. Surveys were carried out twice a month by random walking through roads and footpaths of different parts of the study area. Survey time was either from 07:00-13:00 hr or 15:00-18:00 hr. Butterflies

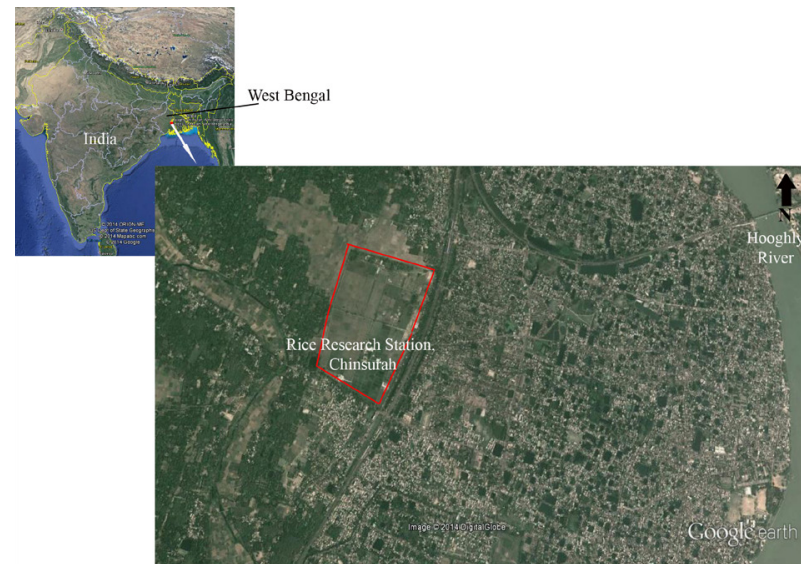

Figure 1. The study area marked with red lines indicates the RRS, Chinsurah. The white boxes are houses and the two curved lines are railway tracks. Inset - Base of the white arrow indicating location of the study area in India. (Maps downloaded from www.googleearth. org).

perched on the vegetation within $2 \mathrm{~m}$ of either side of the walking line were observed and recorded. Butterflies were photographed and identified by comparing the characters of photographs with the published literature (Evans 1932; Haribal 1992; Kehimkar 2008) or web resources (Anonymous 2014; Saji \& Pullatt 2014). No specimens were captured or harmed and thus identification of each and every specimen was based on photographs only. The data analysis was carried out using Microsoft Office Excel, 2007. The status of rarity of the observed species in India was determined following Kehimkar (2008) and Evans (1932).

\section{RESULTS}

The present study documented 70 species of butterfly from this small area of the lower Gangetic plain in West Bengal, India. The entire butterfly fauna represented 53 genera in 14 subfamilies and five families (Table 1). The family Nymphalidae appeared to be the most dominant with $34.3 \%$ of total species representing 14 genera and six subfamilies. The next species-rich family was Lycaenidae with $21.4 \%$ of total species representing three subfamilies (Table 1; Fig. 2). However, generawise the Lycaenidae was richer than Nymphalidae (Fig. 2). Hesperiidae and Pieridae were represented by $18.6 \%$ and $15.7 \%$ of total species, respectively. The lowest species-rich family was Papilionidae with only $10.0 \%$ of total species representing four genera and one subfamily (Table 1; Fig. 2). A detailed checklist of the butterflies including different forms under species are presented in Table 2. The most important documentations were Pale Wanderer Pareronia avator (Moore), Falcate Oakblue Mahathala ameria (Hewitson), and Great Evening Brown 
Table 1. Subfamily wise diversity of the butterflies of RRS, Chinsurah and adjoining area.

\begin{tabular}{|c|c|c|c|}
\hline Family & Subfamily & $\begin{array}{c}\text { Number of } \\
\text { Genera }\end{array}$ & $\begin{array}{c}\text { Number of } \\
\text { Species }\end{array}$ \\
\hline \multirow{2}{*}{ Hesperiidae } & Coeliadinae & 1 & 1 \\
\hline & Hesperiinae & 11 & 12 \\
\hline Papilionidae & Papilioninae & 4 & 7 \\
\hline \multirow{2}{*}{ Pieridae } & Coliadinae & 2 & 5 \\
\hline & Pierinae & 6 & 6 \\
\hline \multirow{3}{*}{ Lycaenidae } & Curetinae & 1 & 1 \\
\hline & Theclinae & 4 & 4 \\
\hline & Polyommatinae & 10 & 10 \\
\hline \multirow{6}{*}{ Nymphalidae } & Danainae & 3 & 4 \\
\hline & Satyrinae & 4 & 8 \\
\hline & Heliconiinae & 2 & 2 \\
\hline & Limenitinae & 2 & 2 \\
\hline & Biblidinae & 1 & 2 \\
\hline & Nymphalinae & 2 & 6 \\
\hline Total: 5 & 14 & 53 & 70 \\
\hline
\end{tabular}

Melanitis zitenius (Herbst) as the status of these species is rare in India (Evans 1932; Kehimkar 2008).

The ratio of species to genus was 1.32. Only the genus Junonia was represented by four species while, the genera, Eurema, Melanitis, Mycalesis, and Graphium, were represented by three species per genus. The genera Pelopidus, Borobo, Papilio, Catopsilia, Danaus, Ariadne and Hypolimnas, were represented by two species per genus and the remaining 41 out of 53 genera were represented by a single species each. The year wise species accumulation curve is slightly upwardly moving even after reaching the $6^{\text {th }}$ year of the survey indicating scope for addition of a few species in the butterfly community of the present study area (Fig. 3). Among the butterflies enlisted in this survey, six species were legally protected under the Wildlife (Protection) Act, 1972 with the Wildlife (Protection) amendment Act 2002 (Anonymous 2003). Of these legally important species, one species was protected under Schedule I (Part-IV), three species under Schedule II and two species under Schedule IV (Table 3).

The representative photographs of each species recorded from the RRS, Chinsurah and adjoining areas are illustrated in Images 1-6. The members of the Family Hesperiidae are presented in Image 1, excepting Common Redeye Matapa aria (Moore). The most active and abundant member of the Family Papilionidae was the Lime Butterfly Papilio demoleus (Linnaeus) (Image 2j) and Common Mormon Papilio polyets (Linnaeus)

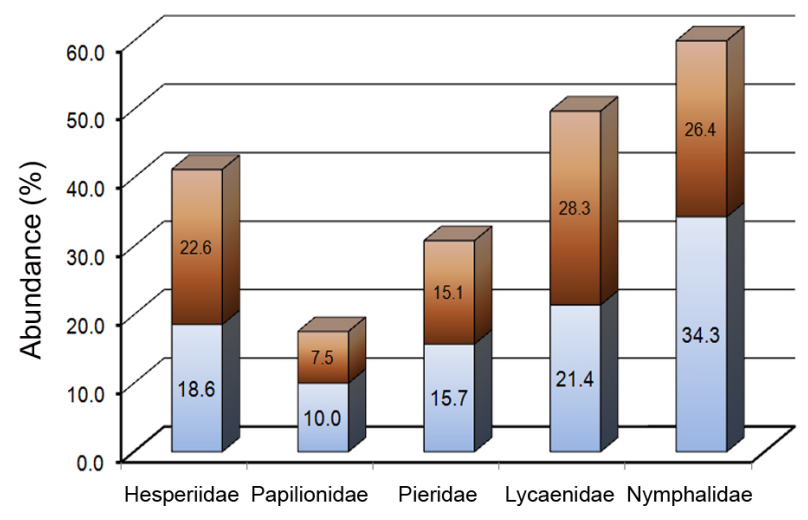

Figure 2. Abundance of the butterflies in and around RRS, Chinsurah. Species-wise (blue) and genus-wise (brown) abundance of butterflies under five families.

(Images $2 \mathrm{f}-\mathrm{i})$. The forms cyrus (Image 2f) and stichius (Images $2 \mathrm{~g}-\mathrm{i}$ ) of female Papilio polyets (Linnaeus) were recorded from the entire study area. Three varieties in the form stichius were observed based on the number of white spots on the hind wing adjacent to cell and the apex of the cell. Two varieties were devoid of any white spot on the apex of the cell and the numbers of white spots adjacent to the cell were either 2 or 3 (Images $2 g, h)$. The other variety was with white spots on the apex of the cell and four white spots adjacent to the cell (Image 2i). Both the forms clytia and dissimilis of Common Mime Chilasa clytia (Linnaeus) were recorded (Images 2d,e). The only one red bodied swallowtail observed here was the Common Rose Atrophaneura aristolochiae (Fabricius) (Image 2k).

The images $3 \mathrm{~d}-\mathrm{j}$ indicate that seven morphological forms or variations of the Common Emigrant Catopsilia pomona (Fabricius) were observed during the entire study period. The other two butterflies of family Pieridae, Mottled Emigrant Catopsilia pyranthe (Linnaeus) and the male of Striped Albatross Appias libythea (Fabricius) were represented by two different morphological forms (Image $3 k, I \& n, o)$. The Indian Sunbeam Curetis thetis (Drury), Falcate Oakblue Mahathala ameria (Hewitson) and Monkey Puzzle Rathinda amor (Fabricius) under family Lycaenidae were observed only once during the entire study period (Images $4 a-c$ ). Only three tiger butterflies were recorded in the survey such as, Plain Tiger Danus chrysippus (Linnaeus), Blue Tiger Tirumala limniace (Cramer) and Striped Tiger Danaus genutia (Cramer) (Images 5a-c). The only species, H. misippus, recorded from the study area which is protected under Schedule I (Part-IV) of the Indian Wildlife (Protection) Act, 1972 and subsequent amendments illustrated in image $6 f$. 

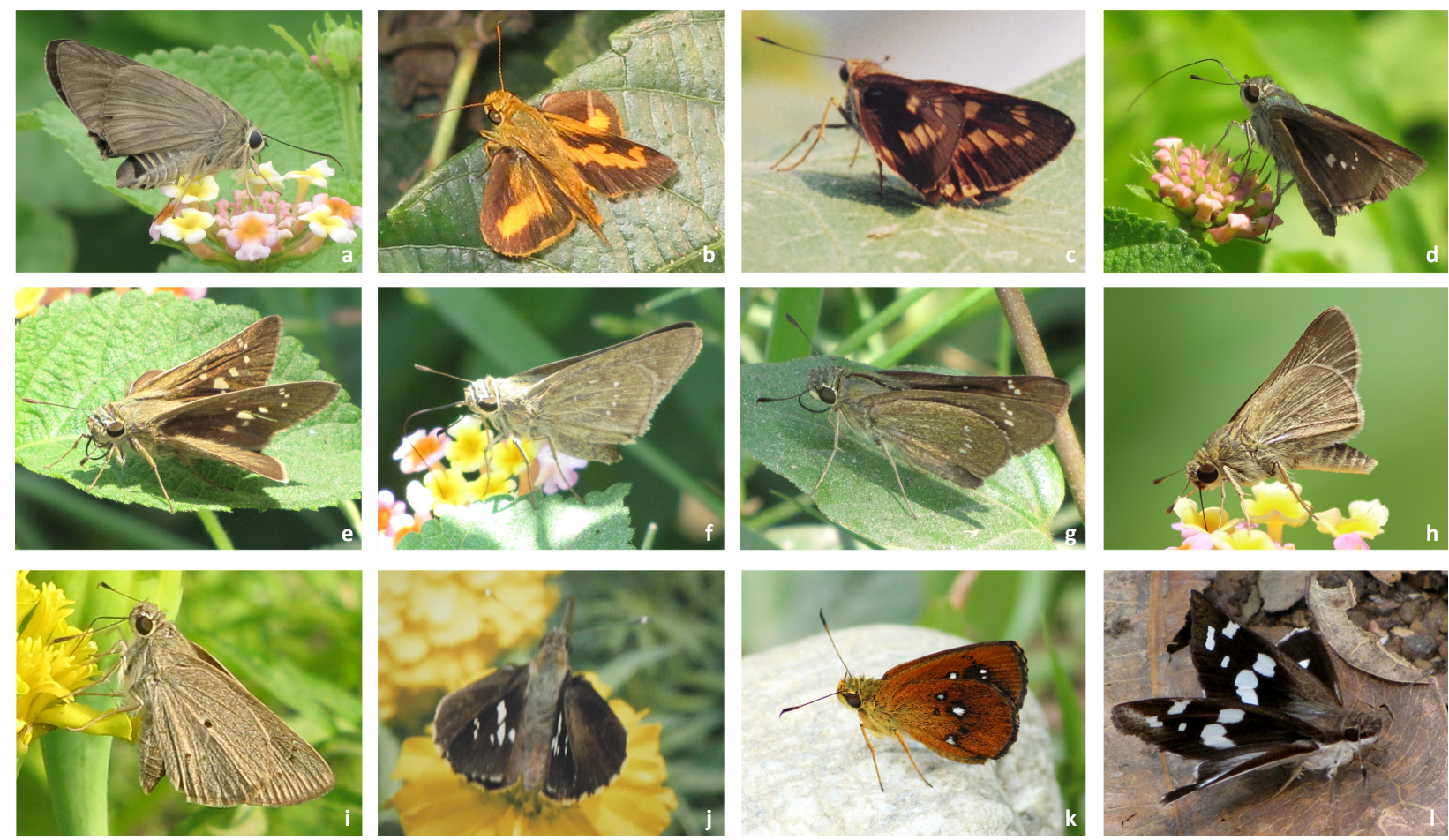

Image 1. Butterflies representing the family Hesperiidae in and around RRS, Chinsurah.

a - Brown Awl B. exclamationis (Fabricius); b - Common Dartlet O. goloides (Moore); c - Plain Palm Dart C. acalle (Hopffer), d - Blank Swift C. Kumara (Moore); e - Conjoined Swift P. conjuncta (Herrich-Schaffer); f - Small Branded Swift P. mathias (Fabricius); g - Rice Swift B. cinnara (Wallace); h - Lesser Rice Swift B. bevani (Moore); i Indian Palm Bob S. gremius (Fabricius); j - Tree Flitter H. adrastus (Stoll); k - Chestnut Bob L. salsala (Moore); I - Grass Demon U. folus (Cramer). (C) Somnath Mandal.
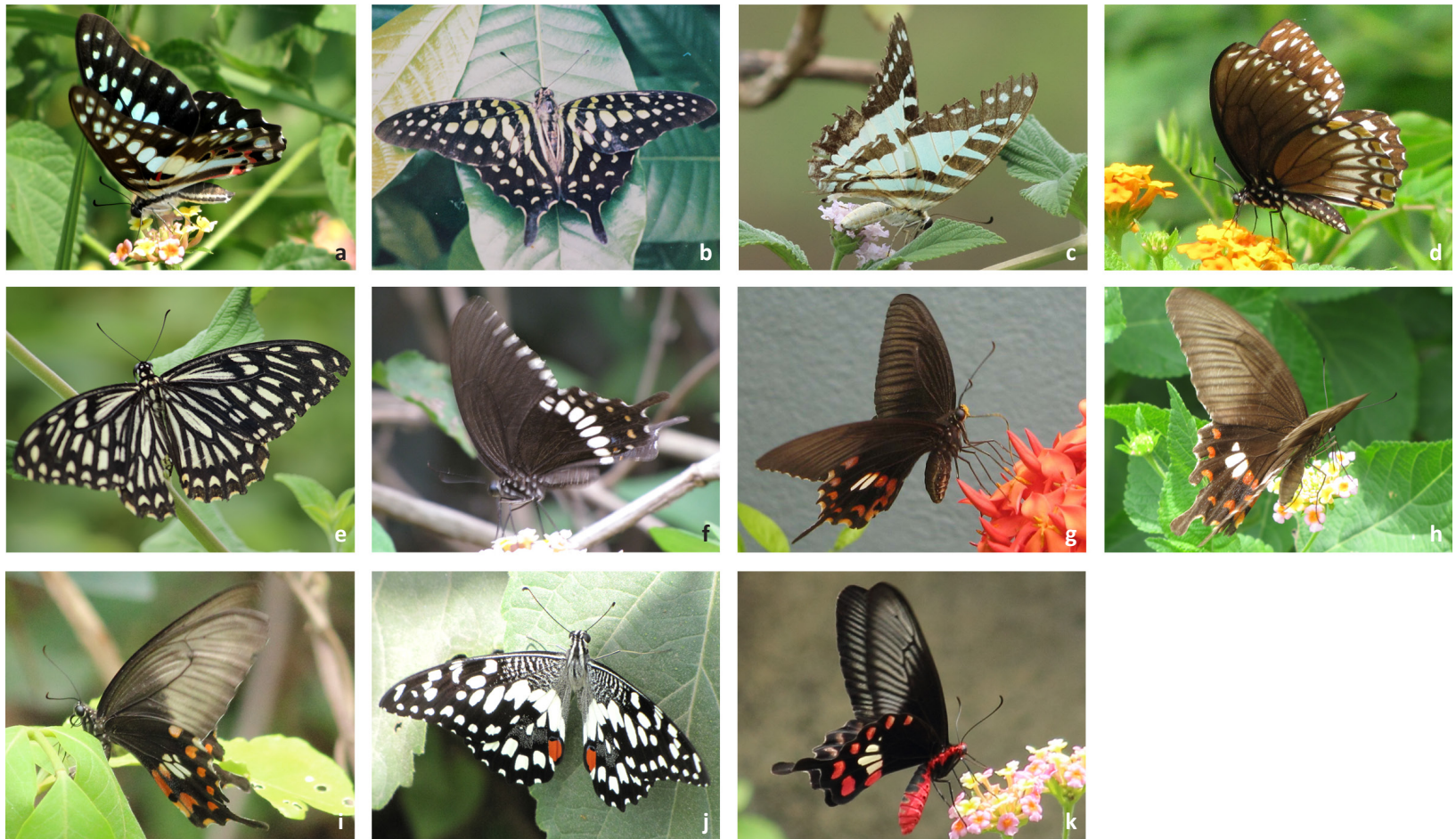

Image 2. Butterflies representing the family Papilionidae in and around RRS, Chinsurah.

a - Common Jay G. doson (C. \& R. Felder); b - Tailed Jay G. agamemnon (Linnaeus); c - Spot Swordtail G. nomius (Esper); d - Common Mime C. clytia (Linnaeus) form: clytia, e - Common Mime C. clytia (Linnaeus) form: dissimilis; f - Common Mormon P. polytes (Linnaeus) form: cyrus; g-i - Common Mormon P. polytes (Linnaeus) form: stichius; j - Lime Butterfly P. demoleus (Linnaeus); $\mathrm{k}$ - Commone Rose P. aristolochiae (Fabricius). (C) Somnath Mandal. 
Table 2. Detailed checklist of the butterflies of RRS, Chinsurah and adjoining area.

\begin{tabular}{|c|c|c|}
\hline & Scientific name & English name \\
\hline \multicolumn{3}{|c|}{ Family: Hesperiidae } \\
\hline \multicolumn{3}{|c|}{ Subfamily: Coeliadinae } \\
\hline 1 & Badamia exclamationis (Fabricius) & Brown Awl \\
\hline \multicolumn{3}{|c|}{ Subfamily: Hesperiinae } \\
\hline 2 & Oriens goloides (Moore) & Common Dartlet \\
\hline 3 & Cephrenes acalle (Hopffer) & Plain Palm-Dart \\
\hline 4 & Caltoris kumara (Moore) & Blank Swift \\
\hline 5 & $\begin{array}{l}\text { Pelopidas conjuncta (Herrich- } \\
\text { Schaffer) }\end{array}$ & Conjoined Swift \\
\hline 6 & Pelopidas mathias (Fabricius) & Small Branded Swift \\
\hline 7 & Borbo cinnara (Wallace) & Rice Swift \\
\hline 8 & Borbo bevani (Moore) & Lesser Rice Swift \\
\hline 9 & Suastus gremius (Fabricius) & Indian Palm Bob \\
\hline 10 & Hyarotis adrastus (Stoll) & Tree Flitter \\
\hline 11 & Matapa aria (Moore) & Common Redeye \\
\hline 12 & Lambrix salsala (Moore) & Chestnut Bob \\
\hline 13 & Udaspes folus (Cramer) & Grass Demon \\
\hline \multicolumn{3}{|c|}{ Family: Papilionidae } \\
\hline \multicolumn{3}{|c|}{ Subfamily: Papilioninae } \\
\hline 14 & Graphium doson (C. \& R. Felder) & Common Jay \\
\hline 15 & Graphium Agamemnon (Linnaeus) & Tailed Jay \\
\hline 16 & Graphium nomius (Esper) & Spot Swordtail \\
\hline 17 & $\begin{array}{l}\text { Chilasa clytia (Linnaeus) } \\
\text { form: clytia \& dissimilis }\end{array}$ & Common Mime \\
\hline 18 & $\begin{array}{l}\text { Papilio polytes (Linnaeus) } \\
\text { form: cyrus \& stichius only }\end{array}$ & Common Mormon \\
\hline 19 & Papilio demoleus (Linnaeus) & Lime Butterfly \\
\hline 20 & $\begin{array}{l}\text { Atrophaneura aristolochiae } \\
\text { (Fabricius) }\end{array}$ & Common Rose \\
\hline \multicolumn{3}{|c|}{ Family: Pieridae } \\
\hline \multicolumn{3}{|c|}{ Subfamily: Coliadinae } \\
\hline 21 & Eurema andersoni (Moore) & One Spot Grass Yellow \\
\hline 22 & Eurema blanda (Boisduval) & Three Spot Grass Yellow \\
\hline 23 & Eurema hecabe (Linnaeus) & Common Grass Yellow \\
\hline 24 & Catopsilia Pomona (Fabricius) & Common Emigrant \\
\hline 25 & Catopsilia pyranthe (Linnaeus) & Mottled Emigrant \\
\hline \multicolumn{3}{|c|}{ Subfamily: Pierinae } \\
\hline 26 & Pareronia avatar (Moore) & Pale Wanderer \\
\hline 27 & Appias libythea (Fabricius) & Striped Albatross \\
\hline 28 & Cepora nerissa (Fabricius) & Common Gull \\
\hline 29 & Delias eucharis (Drury) & Common Jezebel \\
\hline 30 & Leptosia nina (Fabricius) & Psyche \\
\hline 31 & Belenois aurota (Fabricius) & Pioneer \\
\hline \multicolumn{3}{|c|}{ Family: Lycaenidae } \\
\hline \multicolumn{3}{|c|}{ Subfamily: Curetinae } \\
\hline 32 & Curetis thetis (Drury) & Indian Sunbeam \\
\hline \multicolumn{3}{|c|}{ Subfamily: Theclinae } \\
\hline 33 & Mahathala ameria (Hewitson) & Falcate Oakblue \\
\hline
\end{tabular}

\begin{tabular}{|l|l|l|}
\hline & Scientific name & English name \\
\hline 34 & Rathinda amor (Fabricius) & Monkey Puzzle \\
\hline 35 & Rapala manea (Hewitson) & Slate Flash \\
\hline 36 & Spindasis vulcanus (Fabricius) & Common Silverline \\
\hline
\end{tabular}

Subfamily: Polyommatinae

\begin{tabular}{|l|l|l|}
\hline 37 & Castalius rosimon (Fabricius) & Common Pierrot \\
\hline 38 & Catochrysops Strabo (Fabricius) & Forget-Me-Not \\
\hline 39 & Tarucus nara (Kollar) & Rounded Pierrot \\
\hline 40 & Pseudozizeeria maha (Kollar) & Pale Grass Blue \\
\hline 41 & Zizeeria karsandra (Moore) & Dark Grass Blue \\
\hline 42 & Zizina otis (Fabricius) & Lesser Grass Blue \\
\hline 43 & Zizula hylax (Fabricius) & Tiny Grass Blue \\
\hline 44 & Neopithecops zalmora (Butler) & Quaker \\
\hline 45 & Euchrysops cnejus (Fabricius) & Gram Blue \\
\hline 46 & Chilades lajus (Stoll) & Lime Blue \\
\hline
\end{tabular}

Family: Nymphalidae

Subfamily: Danainae

\begin{tabular}{|l|l|l|}
\hline 47 & Tirumala limniace (Cramer) & Blue Tiger \\
\hline 48 & Danaus genutia (Cramer) & Striped Tiger \\
\hline 49 & Danaus chrysippus (Linnaeus) & Plain Tiger \\
\hline 50 & Euploea core (Cramer) & Common Crow \\
\hline \multicolumn{2}{|l}{ Subfamily: Satyrinae }
\end{tabular}

Subfamily: Satyrinae

\begin{tabular}{|c|c|c|}
\hline 51 & Melanitis leda (Linnaeus) & Common Evening Brown \\
\hline 52 & Melanitis phedima (Cramer) & Dark Evening Brown \\
\hline 53 & Melanitis zitenius (Herbst) & Great Evening Brown \\
\hline 54 & Elymnias hypermnestra (Linnaeus) & Common Palmfly \\
\hline 55 & Mycalesis perseus (Fabricius) & Common Bushbrown \\
\hline 56 & Mycalesis mineus (Linnaeus) & Dark-Brand Bushbrown \\
\hline 57 & Mycalesis visala (Moore) & Long-Brand Bushbrown \\
\hline 58 & Ypthima huebneri (Kirby) & Common Fourring \\
\hline \multicolumn{3}{|c|}{ Subfamily: Heliconiinae } \\
\hline 59 & Acraea violae (Fabricius) & Tawny Coster \\
\hline 60 & Phalanta phalantha (Drury) & Common Leopard \\
\hline
\end{tabular}

Subfamily: Limenitinae

\begin{tabular}{|l|l|l|}
\hline 61 & Moduja procris (Cramer) & Commander \\
\hline 62 & Euthalia aconthea (Cramer) & Common Baron \\
\hline \multicolumn{2}{|l|}{ Subfamily: Biblidinae }
\end{tabular}

Subfamily: Biblidinae

\begin{tabular}{|l|l|l|}
\hline 63 & Ariadne ariadne (Linnaeus) & Angled Castor \\
\hline 64 & Ariadne merione (Cramer) & Common Castor \\
\hline \multicolumn{2}{|l|}{ Subfamily: Nymphalinae } & Blue Pansy \\
\hline 65 & Junonia orithiya (Linnaeus) & Grey Pansy \\
\hline 66 & Junonia atlites (Linnaeus) & Peacock Pansy \\
\hline 67 & Junonia almana (Linnaeus) & Lemon Pansy \\
\hline 68 & Junonia lemonias (Linnaeus) & Great Eggfly \\
\hline 69 & Hypolimnas bolina (Linnaeus) & Danaid Eggfly \\
\hline 70 & Hypolimnas misippus (Linnaeus) & \\
\hline
\end{tabular}



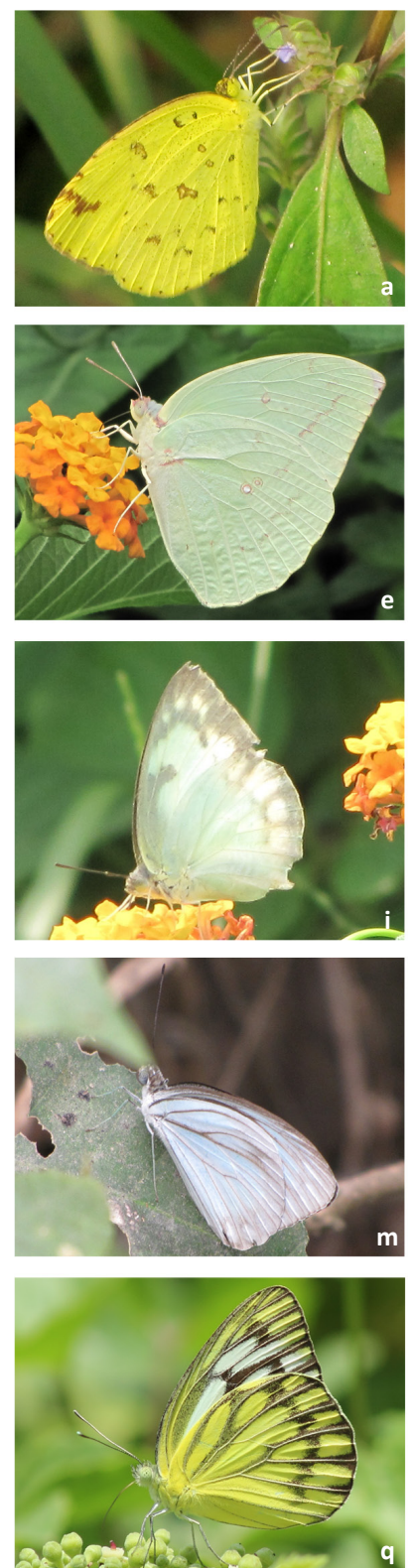
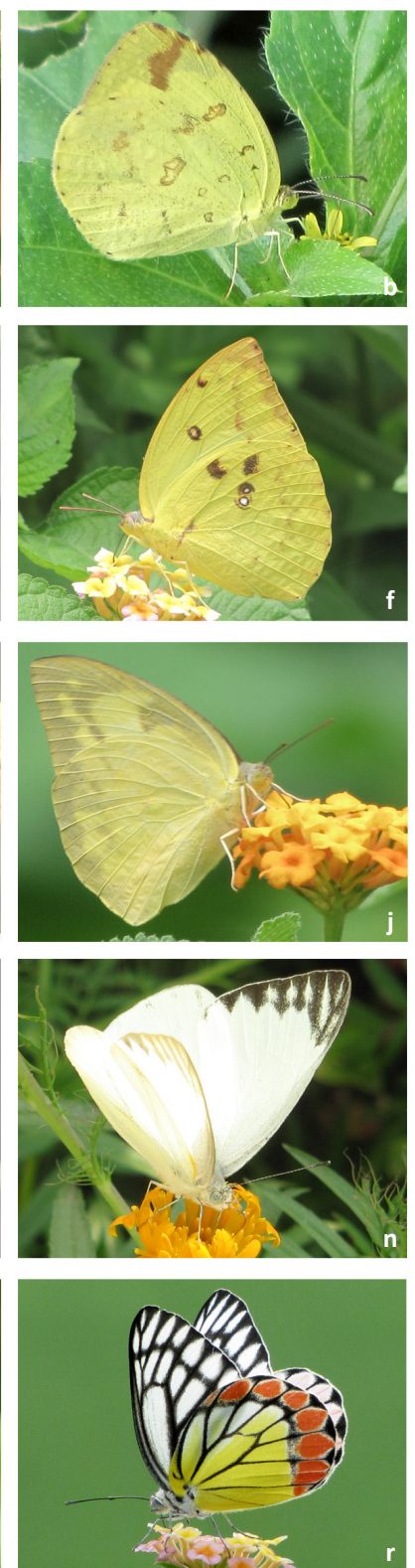
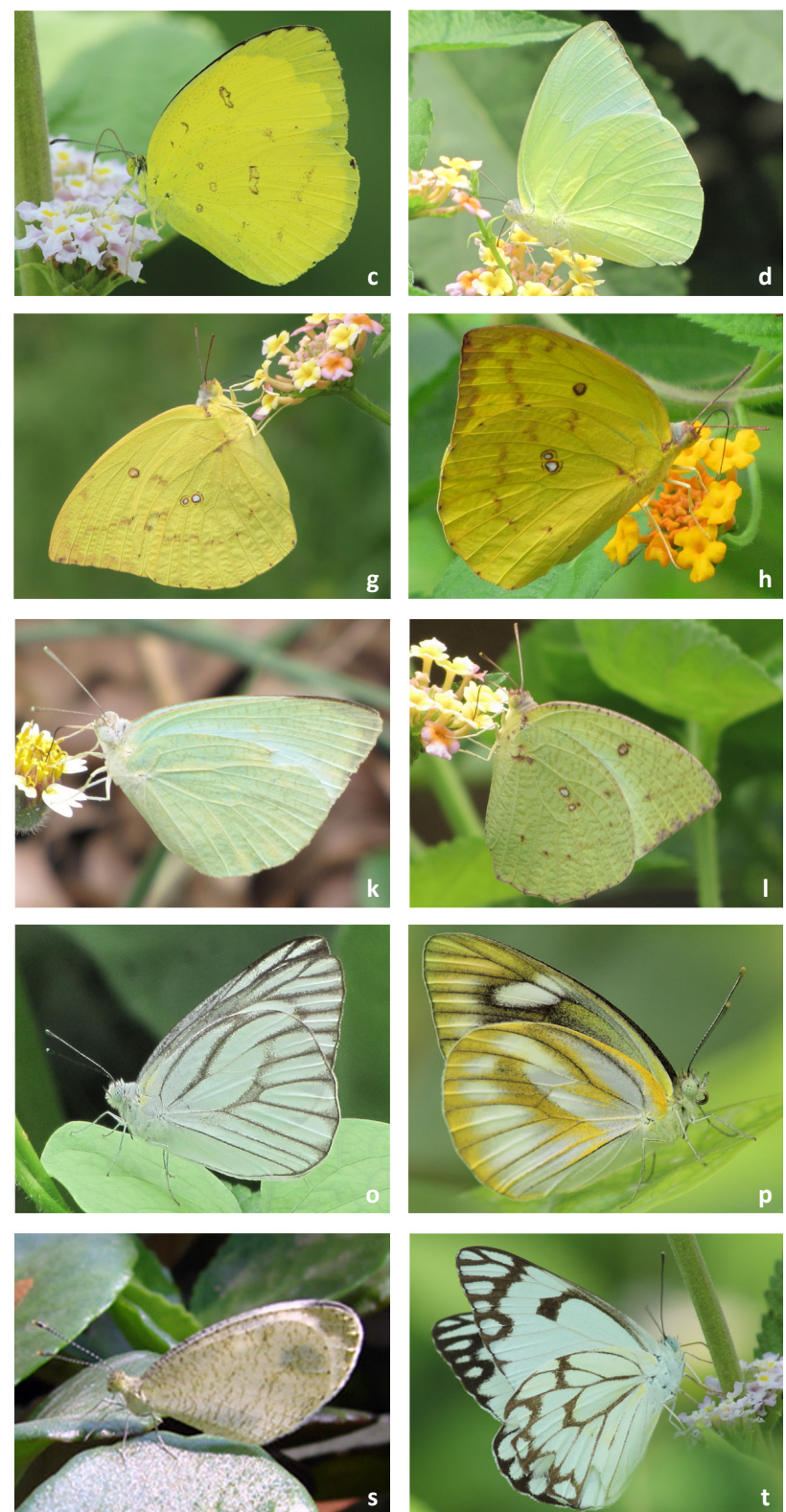

Image 3. Butterflies representing the family Pieridae in and around RRS, Chinsurah.

a - One Spot Grass Yellow E. andersoni (Moore); b - Three Spot Grass Yellow E. blanda (boisduval); c - Common Grass Yellow E. hecabe (Linnaeus); d-j - Common Emigrant C. pomona (Fabricius); k\&l - Mottled Emigrant C. pyranthe (Linnaeus); $\mathrm{m}$ - Pale Wanderer P. avatar (Moore); n\&o - Striped Albatross A. libythea (Fabricius) male; p - Striped Albatross A. libythea (Fabricius) female; q - Common Gull C. nerissa (Fabricius); $r$ - Common Jezebel D. eucharis (Drury); s - Psyche L. nina (Fabricius); $\mathrm{t}$ - Pioneer B. aurota (Fabricius). (C) Somnath Mandal.

\section{DISCUSSION}

The species diversity of butterfly in Chinsurah seems to be comparable with Sundarban Biosphere Reserve, West Bengal, India (Chowdhuri 2014). Although the habitat in the present study area is different, about 59 species appeared to be similar with the Sundarban Biosphere Reserve. Predominance of the family Nymphalidae with respect to species diversity in the present study area is in good correlation with Neora Valley National Park in West
Bengal (Sengupta et al. 2014) as well as other regions in India starting from Himalayan landscape (Singh 2009, 2012; Kunte et al. 2012) through central India (Palot \& Soniya 2003; Chandrakar et al. 2007; Singh 2010; Tiple 2011, 2012) to Western Ghats (Mathew \& Rahamathulla 1993; Kunte 1997; Kunte et al. 1999; Arun 2002; Eswaran \& Pramod 2005; Kumar et al. 2007; Dolia et al. 2008) and southern India (Ramesh et al. 2010; Murugessan 2013).

The number of genera representing Lycaenidae 
Table: 3. The butterflies of RRS, Chinsurah and adjoining area protected under various schedules of Wildlife (Protection) Act, 1972.

\begin{tabular}{|c|l|l|l|}
\hline Schedule & Family & Scientific name & Common name \\
\hline \multirow{2}{*}{ I } & Nymphalidae & $\begin{array}{l}\text { Hypolimnas misippus } \\
\text { (Linnaeus) }\end{array}$ & Danaid Eggfly \\
\hline \multirow{4}{*}{ II } & Lycaenidae & $\begin{array}{l}\text { Euchrysops cnejus } \\
\text { (Fabricius) }\end{array}$ & Gram Blue \\
\cline { 2 - 4 } & Lycaenidae & $\begin{array}{l}\text { Mahathala ameria } \\
\text { (Hewitson) }\end{array}$ & $\begin{array}{l}\text { Falcate } \\
\text { Oakblue }\end{array}$ \\
\cline { 2 - 4 } & Nymphalidae & $\begin{array}{l}\text { Melanitis zitenius } \\
\text { (Herbst) }\end{array}$ & $\begin{array}{l}\text { Great Evening } \\
\text { Brown }\end{array}$ \\
\hline \multirow{3}{*}{ IV } & Hesperiidae & Hyarotis adrastus (Stoll) & Tree Flitter \\
\cline { 2 - 5 } & Pieridae & $\begin{array}{l}\text { Appias libythea } \\
\text { (Fabricius) }\end{array}$ & $\begin{array}{l}\text { Striped } \\
\text { Albatross }\end{array}$ \\
\hline
\end{tabular}

was more than Nymphalidae and other families. The inherent reason may be the single species per genus distribution of all the members representing the family. Furthermore, six genera, namely, Danaus, Melanitis, Mycalesis, Ariadne, Junonia and Hypolimnas under the Family Nymphalidae were represented by more than one species that reduced the number of representative genera. Recording of seven morphological forms in the species C. Pomona (Fabricius) is consistent with published literatures (Haribal 1992; Kehimkar 2008).

Observation of 70 butterfly species including three rare species in an urbanized area seems to be encouraging for conservation purposes. The species accumulation curve indicates scope for the addition of some new species upon further sampling in this rapidly degrading habitat. Very low species to genus ratio indicates the presence of strong intra-generic competition (Elton 1946). Additional to that, six species in the study area are legally protected under Schedule I, II and IV of the Wildlife (Protection) Act, 1972 with the Wildlife (Protection) amendment Act 2002 (Anonymous 2003). Reports on butterfly diversity from other habitats in the vicinity of human habitation like the Tropical Forest Research Institute campus in Madhya Pradesh and Ossudu Lake area in Puducherry and Tamil Nadu also indicate the presence of rich butterfly diversity (Tiple 2012; Murugesan et al. 2013). Very poor abundance of butterflies excepting one common tiger butterfly, two very common swallowtail butterflies and two emigrants, in the present study area may be due to the increasing destruction of larval food plants. The conservation scenario in urban areas may be improved by preserving the weeds and shrubs in unused pieces of land. Creation of vacant lands by demolishing old and abandoned structures could offer space for preserving declining species as well as restoration of ecosystem

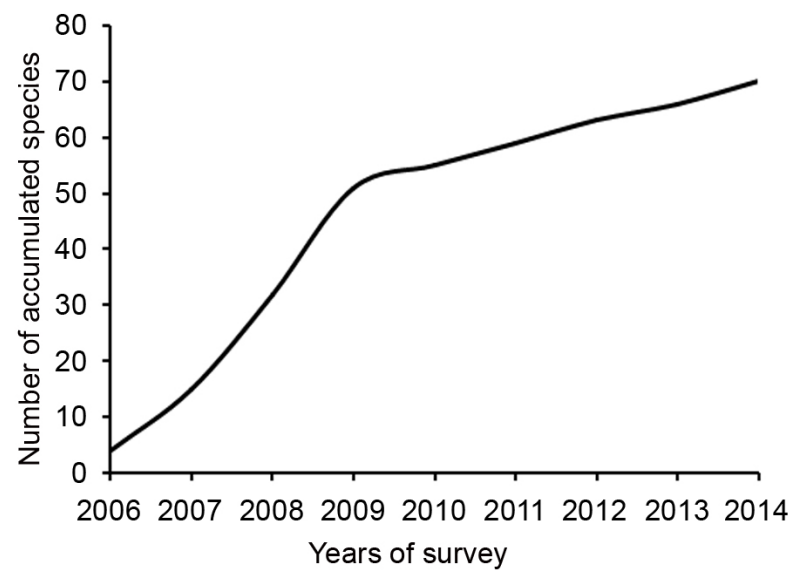

Figure 3. Species accumulation curve of the butterflies in and around RRS, Chinsurah.

functions and food production in urban areas (Gardiner et al. 2013). Conservation of these important pollinators is essential for sustainable development. Designing suitable methodology for conservation in urbanized areas involving local people is awaiting further research.

\section{REFERENCES}

Adhikari, B., M.K. Bag, M.K. Bhowmick \& C. Kundu (2011). Status Paper on Rice in West Bengal. Rice Knowledge Management Portal $<$ http://www.rkmp.co.in> 1-88pp.

Anonymous (2003). The Wildlife (Protection) Act, 1972 with the Wildlife (Protection) Amendment Act, 2002. The Gazette of India, 148pp. Downloaded on 12 October 2013.

Anonymous (2014). Mahathala ameria Hewitson, 1862 - Falcate Oakblue. In: Kunte, K., S. Kalesh \& U. Kodandaramaiah (eds.). Butterflies of India, v. 2.10. Indian Foundation for Butterflies. <http://www.ifoundbutterflies.org/sp/2113/Mahathala-ameria> Downloaded on 25th May 2014.

Arun, P.R. (2002). Butterflies of Siruvani forest of Western Ghats, with notes on their seasonality. Zoos' Print Journal 18(2): 1003-1006; http://dx.doi.org/10.11609/JoTT.ZPJ.18.2.1003-6

Bates, A.J., J.P. Sadler, D. Grundy, N. Lowe, G. Davis, D. Baker, M. Bridge, R. Freestone, D. Gardner, C, Gibson, R. Hemming, S. Howarth, S. Orridge, M. Shaw, T. Tams \& H. Young (2014). Garden and landscape-scale correlates of moths of differing conservation status: significant effects of urbanization and habitat diversity. PlosOne 9(1): e86925; http://dx.doi.org/10.1371/journal. pone.0086925

Bhowmick, M.K., M.C. Dhara, S. Singh, M.H. Dar \& U.S. Singh (2014). Improved management options for submergence-tolerant (sub1) rice genotype in flood-prone rainfed lowlands of West Bengal. American Journal of Plant Sciences 5: 14-23; http://dx.doi. org/10.4236/ajps.2014.51003

Chandrakar, M., S. Palekar \& S. Chandrakar (2007). Butterfly fauna of Melghat Region, Maharashtra. Zoos' Print Journal 22(7): 27622764; http://dx.doi.org/10.11609/JoTT.ZPJ.1479.2762-4

Chowdhury, S. (2014). Butterflies of Sundarban Biosphere Reserve, West Bengal, eastern India: a preliminary survey of their taxonomic diversity, ecology and their conservation. Journal of Threatened Taxa 6(8): 6082-6092; http://dx.doi.org/10.11609/JoTT.o3787.6082-92

Dolia, J., M.S. Devy, N.A. Aravind \& A. Kumar (2008). Adult butterfly communities in coffee plantations around a protected area in the 

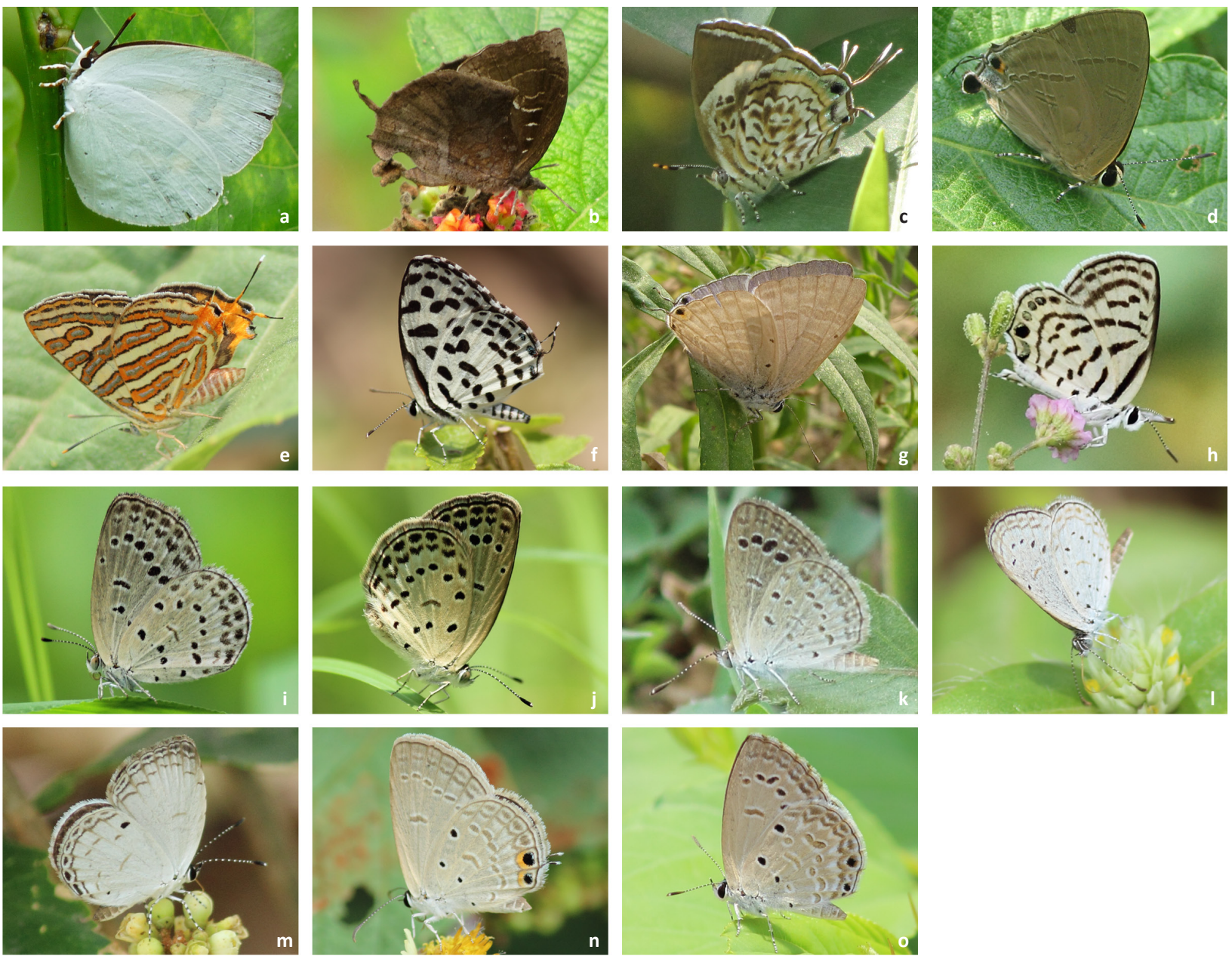

Image 4. Butterflies representing the family Lycaenidae in and around RRS; Chinsurah.

a - Indian Sunbeam C. thetis (Drury); b - Falcate Oakblue M. ameria (Hewitson); c - Monkey Puzzle R. amor (Fabricius); d - Slate Flash R. manea (Hewitson); e - Common Silverline S. vulcanus (Fabricius); f - Common Pierrot C. rosimon (Fabricius); g - Forget-Me-Not C. Strabo (Fabricius); h - Rounded Pierrot T. nara (Kollar); i - Pale Grass Blue P. maha (Kollar); - Dark Grass Blue Z. karsandra (Moore); $\mathrm{k}$ - Lesser Grass Blue Z. otis (Fabricius); I - Tiny Grass Blue Z. hylax (Fabricius); m - Quaker N. zalmora (Butler); n - Gram Blue E. cnejus (Fabricius); o - Lime Blue C. Iajus (Stoll). (c) Somnath Mandal.

Western Ghats, India. Animal Conservation 11: 26-34; http://dx.doi. org/10.1111/j.1469-1795.2007.00143.x

Elton, C. (1946). Competition and the structure of ecological communities. Journal of Animal Ecology 15: 54-68; http://dx.doi. org/10.2307/1625

Eswaran, R. \& P. Pramod (2005). Structure of butterfly community of Anaikatty Hills, Western Ghats. Zoos' Print Journal 20(8): 19391942; http://dx.doi.org/10.11609/JoTT.ZPJ.1330.1939-42

Evans, J.H. (1932). Identification of Indian Butterflies. Bombay Natural History Society, Mumbai, 454pp.

Gardiner, M.M., C.E. Burkman \& S.P. Prajzner (2013). The value of urban vacant land to support arthropod biodiversity and ecosystem services. Environmental Entomology 42(6): 1123-1136; http://dx.doi.org/10.1603/EN12275

Haribal, M. (1992). The Butterflies of Sikkim Himalaya and Their Natural History, Sikkim. Sikkim Natural Conservation Foundation, $217 \mathrm{pp}$.

Kehimkar, I. (2008). The Book of Indian Butterflies. Bombay Natural History Society, Oxford University Press, xvi+497pp.

Kumar, M.P., B.B. Hosetti, H.C. Poomesha \& G.H.T. Raghavendra (2007). Butterflies of the Tiger Lion Safari, Thyavarekoppa, Shimoga, Karnataka. Zoos' Print Journal 22(8): 2805; http://dx.doi.
org/10.11609/JoTT.ZPJ.1594.2805

Kunte, K. (1997). Seasonal patterns in butterfly abundance and species diversity in four tropical habitats in the northern Western Ghats. Journal of Bioscience 22(5): 593-603; http://dx.doi.org/10.1007/ BF02703397

Kunte, K., A. Joglekar, G. Utkarsh \& P. Pramod (1999). Patterns of butterfly, bird and tree diversity in the Western Ghats. Current Science 29: 1-14.

Kunte, K., S. Sondhi, B.M. Sangma, R. Lovalekar, K. Tokekar \& G. Agavekar (2012). Butterflies of the Garo Hills of Meghalaya, northeastern India: their diversity and conservation. Journal of Threatened Taxa 4(10): 2933-2992; http://dx.doi.org/10.11609/ JoTT.02945.2933-92

Mathew, G. \& V.K. Rahamathulla (1993). Studies on the butterflies of Silent Valley National Park. Entomon 18: 185-192.

Murugesan, M., P.R. Arun \& B.A.K. Prusty (2013). The butterfly community of an urban wetland system - a case study of Oussudu Bird Sanctuary, Puducherry, India. Journal of Threatened Taxa 5(12): 4672-4678; http://dx.doi.org/10.11609/JoTT.03056.4672-8

New, T.R. (2011). Launching and steering flagship Lepidoptera for conservation benefit. Journal of Threatened Taxa 3(6): 1805-1817; http://dx.doi.org/10.11609/JoTT.o2621.1805-17 

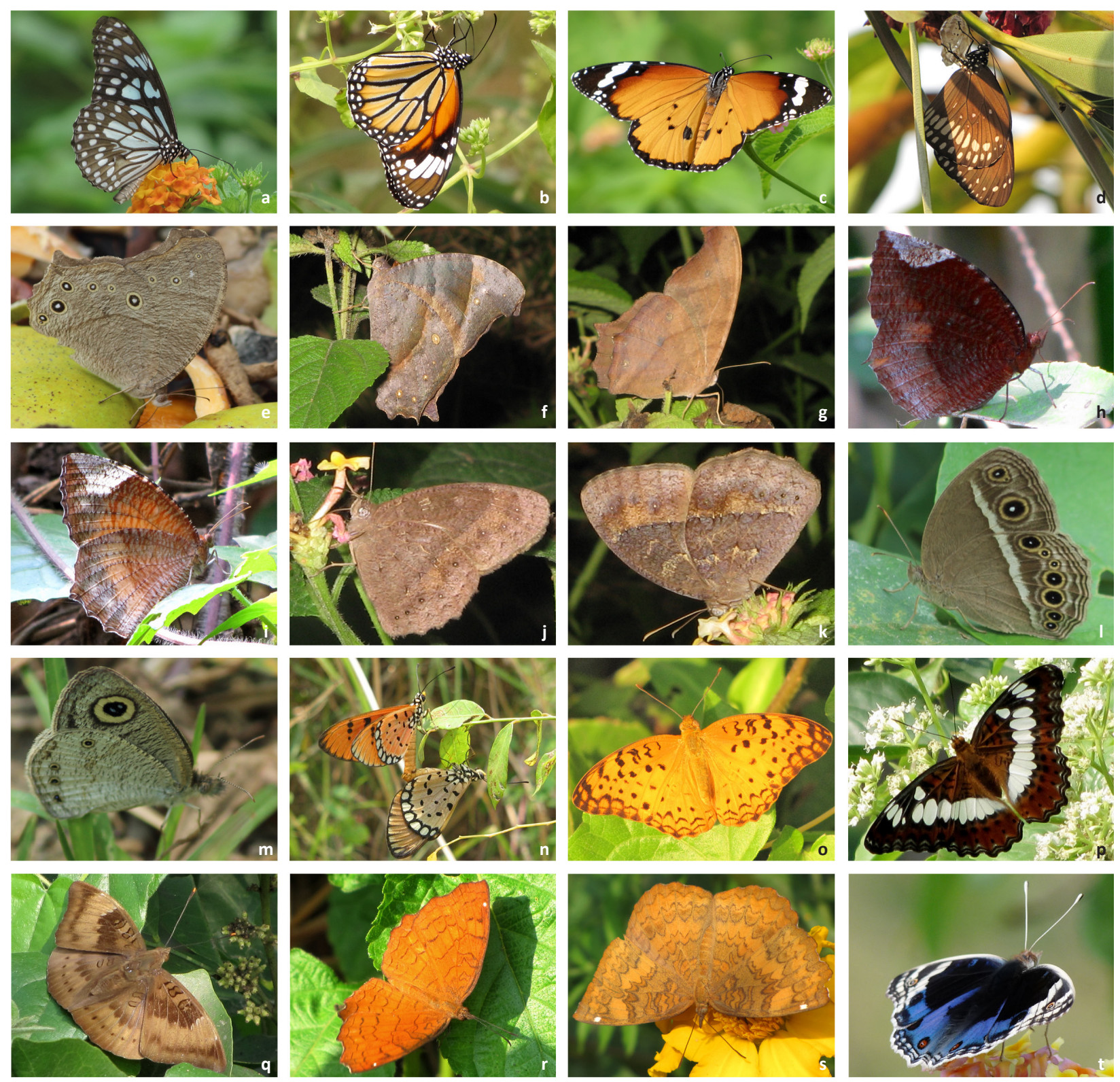

Image 5. Butterflies representing the family Nymphalidae in and around RRS; Chinsurah.

a - Blue Tiger T. limniace (Cramer); b- Striped Tiger D. genutia (Cramer); c - Plain Tiger D. chrysippus (Linnaeus); d - Common Crow E. core (Cramer); e - Common Evening Brown M. leda (Linnaeus); f - Dark Evening Brown M. phedima (Cramer); g - Great Evening Brown M. zitenius (Herbst); h - Common Palmfly E. hypermnestra (Linnaeus) male; i - Common Palmfly E. hypermnestra (Linnaeus) female; j - Common Bushbrown M. perseus (Fabricius); k - Dark-Brand Bushbrown M. mineus (Linnaeus); I - Long Brand Bushbrown M. visala (Moore); $\mathrm{m}$ - Common Fourring Y. hubeneri (Kirby); $\mathrm{n}$ - Tawny Coster A. violae (Fabricius); o - Common Leopard P. phalantha (Drury); $\mathrm{p}$ - Commander M. procris (Cramer); q - Common Baron E. aconthea (Cramer); $r$ - Angled Castor A. ariadne (Linnaeus); s - Common Castor A. merione (Cramer); t - Blue Pansy J. orithiya (Linnaeus). (c) Somnath Mandal.

Palot, M.J. \& V.P. Soniya (2003). A preliminary report on the Butterflies of Lonar Crater Lake, Buldhana District, Maharashtra. Zoos' Print Journal 18(11): 1267-1268; http://dx.doi.org/10.11609/JoTT. ZPJ.18.11.1267-8

Saji, K. \& S. Pullatt (2014). Cephrenes acalle Höpffer, 1874 - Plain PalmDart. In: Kunte, K., S. Kalesh \& U. Kodandaramaiah (eds.). Butterflies of India, v. 2.10. Indian Foundation for Butterflies. http://www. ifoundbutterflies.org/sp/1038/Cephrenes-acalle. Downloaded on 25 May 2014.
Sengupta, P., K.K. Banerjee \& N. Ghorai (2014). Seasonal diversity of butterflies and their larval food plants in the surroundings of upper Neora Valley National Park, a sub-tropical broad leaved hill forest in the eastern Himalayan landscape, West Bengal, India. Journal of Threatened Taxa 6(1): 5327-5342; http://dx.doi.org/10.11609/ JoTT.03446.5327-42

Singh, A.P. (2009). Butterflies of Kedarnath Musk Deer Reserve, Garhwal Himalaya, India. Journal of Threatened Taxa 1(1): 37-48; http://dx.doi.org/10.11609/JoTT.o1873.37-48 

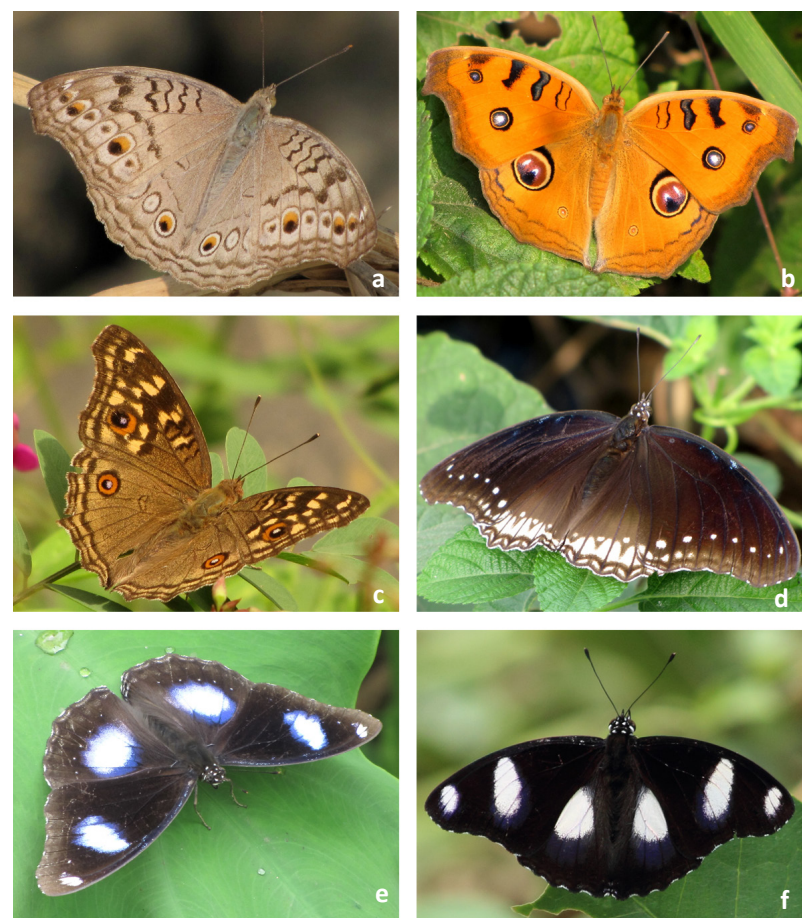

Image 6. Butterflies representing the family Nymphalidae in and around RRS, Chinsurah.

a - Grey Pansy J. athletes (Linnaeus); b - Peacock Pansy J. almana (Linnaeus); c - Lemon Pansy J. lemonias (Linnaeus); d - Great Eggfly H. bolina (Linnaeus) female; e - Great Eggfly $\boldsymbol{H}$. bolina (Linnaeus) male; f - Danaid Eggfly H. misippus (Linnaeus). (C) Somnath Mandal.
Singh, A.P. (2010). Butterfly diversity in tropical moist deciduous sal forests of Ankua Reserve Forest, Koina Range, Saranda Division, West Singhbhum District, Jharkhand, India. Journal of Threatened Taxa 2(9): 1130-1139; http://dx.doi.org/10.11609/JoTT.o2274.1130-9

Singh, A.P. (2012). Lowland forest butterflies of the Sankosh River catchment, Bhutan. Journal of Threatened Taxa 4(12): 3085-3102; http://dx.doi.org/10.11609/JoTT.o2625.3085-102

Tiple, A.D. (2011). Butterflies of Vidarbha region, Maharashtra State, central India. Journal of Threatened Taxa 3(1): 1469-1477; http:// dx.doi.org/10.11609/JoTT.o2397.1469-77

Tiple, A.D. (2012). Butterfly species diversity, relative abundance and status in Tropical Forest Research Institute, Jabalpur, Madhya Pradesh, central India. Journal of Threatened Taxa 4(7): 2713-2717; http://dx.doi.org/10.11609/JoTT.o2656.2713-7

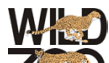

